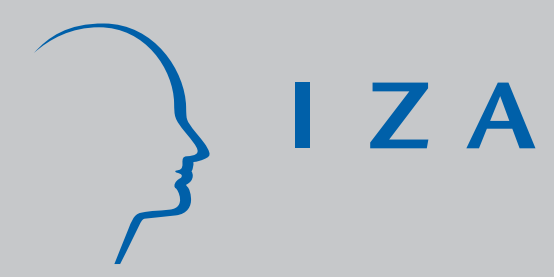

IZA DP No. 2714

'Voluntary' and 'Involuntary' Early Retirement: An International Analysis

David Dorn

Alfonso Sousa-Poza

March 2007 


\title{
'Voluntary' and 'Involuntary' Early Retirement: An International Analysis
}

\author{
David Dorn \\ University of St. Gallen \\ Alfonso Sousa-Poza \\ University of Hohenheim, \\ University of St. Gallen and IZA
}

Discussion Paper No. 2714

March 2007

\author{
IZA \\ P.O. Box 7240 \\ 53072 Bonn \\ Germany \\ Phone: +49-228-3894-0 \\ Fax: +49-228-3894-180 \\ E-mail: iza@iza.org
}

\begin{abstract}
Any opinions expressed here are those of the author(s) and not those of the institute. Research disseminated by IZA may include views on policy, but the institute itself takes no institutional policy positions.

The Institute for the Study of Labor (IZA) in Bonn is a local and virtual international research center and a place of communication between science, politics and business. IZA is an independent nonprofit company supported by Deutsche Post World Net. The center is associated with the University of Bonn and offers a stimulating research environment through its research networks, research support, and visitors and doctoral programs. IZA engages in (i) original and internationally competitive research in all fields of labor economics, (ii) development of policy concepts, and (iii) dissemination of research results and concepts to the interested public.
\end{abstract}

IZA Discussion Papers often represent preliminary work and are circulated to encourage discussion. Citation of such a paper should account for its provisional character. A revised version may be available directly from the author. 


\section{ABSTRACT \\ 'Voluntary' and 'Involuntary' Early Retirement: An International Analysis}

Recent literature makes a distinction between 'voluntary' and 'involuntary' early retirement, where 'involuntary' early retirement results from employment constraints rather than from a preference for leisure relative to work. This paper analyzes 'voluntary' and 'involuntary' early retirement based on international microdata covering 19 industrialized countries. The results show that 'involuntary' early retirement is particularly widespread in Continental Europe. Countries facing economic recessions and having strict employment protection legislation have higher shares of 'involuntary' retirements among early retirees. Generous early retirement provisions of the social security system do not only make 'voluntary' early retirement more attractive for individuals, but also induce firms to push more employees into early retirement.

JEL Classification: J14, J21, J22, J26

Keywords: early retirement, involuntary early retirement, social security, pensions

Corresponding author:

Alfonso Sousa-Poza

Institute for Household and Consumer Economics

University of Hohenheim

Fruwirthstr. 48, Kavaliershaus 4116

70599 Stuttgart

Germany

E-mail: alfonso.sousa-poza@uni-hohenheim.de

\footnotetext{
Previous versions of this paper were presented at the 4th Meeting on Social Security and Complementary Pension Systems, Lisbon, Portugal, 2005, at the CEBR/CESifo Conference on Pension Reform, Copenhagen, Denmark, 2005, and at the UK Department of Work and Pensions WPEG Conference in York, Great Britain, 2005. We thank the participants of these conferences for their comments. Moreover, we want to thank Monika Bütler, Robert Hutchens and Philip Taylor for helpful comments and Robert Duval for providing data. An earlier version of this paper was printed as CESifo working paper no. 1542. The usual disclaimer applies.
} 


\section{'Voluntary’ and 'Involuntary' Early Retirement:}

\section{An International Analysis}

\section{Introduction}

The trend toward earlier retirement has been one of the most important labor market developments in the past fifty years. During this period, participation rates of older workers have fallen in virtually all OECD countries. The decrease in labor market participation implies considerable economic costs, particularly through social security benefit payments and a lower tax base.

A large body of economic literature has analyzed workers' choice of retirement age. According to this literature, a worker's retirement decision is based on an assessment of future streams of wages and pension payments from public and private sources. The worker chooses an optimal retirement date such as to maximize future expected utility.

A frequent criticism of life-cycle retirement models challenges the key underlying assumption: Individuals are supposed free to choose the optimal retirement age. But according to Hurd (1990, p. 597), "assuming that the worker could choose hours and years of work freely at the preretirement wage, which is the only one observed for that worker, leads to the incorrect conclusion that the worker retired because of a shift in the position or shape of his indifference curves, when, in fact, he retired because of unobserved employment constraints." Desmet et al. (2005) point out that this problem is particularly relevant in a European context where anecdotal evidence suggests that large-scale industry restructuring has been a cause for employment constraints that led to early retirement. 
Therefore, in recent literature including Desmet et al. (2005) and Smith (2006), an explicit distinction between 'voluntary' and 'involuntary' early retirement has been made. 'Voluntary' early retirement is understood as a retirement that is caused by a relative preference for leisure versus the feasible alternative of continuing work. Conversely, 'involuntary' early retirement refers to a retirement that results from a situation with (often unexpected) employment constraints. While such an 'involuntary' early retirement is still the result of a rational choice of the worker, the choice is strongly restricted by the lack of employment options.

Employment constraints for older workers are not unusual in Europe. In a comprehensive review of empirical studies from various European countries, Taylor (2001) concludes that employers' attitudes and policies toward older employees imply a strong age discrimination in the labor market, for instance by setting age limits in recruiting. ${ }^{1}$ Once older workers are made redundant with their current employer, it will hence be very difficult to find new jobs, and they will likely have little other choice than moving into early retirement.

The importance of studying 'involuntary' early retirement is also highlighted by the fact that 'voluntary' and 'involuntary' retirement lead to different post-retirement behavior. While it is difficult to explain the empirically observed fall of consumption after retirement with 'voluntary' early retirement as a result of life-cycle optimization (hence the name 'retirementconsumption puzzle' for this issue), Smith (2006) shows that a significant drop in consumption in fact only occurs in case of an often unexpected 'involuntary' retirement.

Although sufficient anecdotal evidence on the importance of the phenomenon of 'involuntary' early retirement exists (e.g. Schmähl 2003, Henkens and van Dalen 2003, Herz 1995), we are not aware of empirical studies that document the extent and determinants of

1 Constraints to the employment of older workers can also stem from regulations of the social security system. For instance, firms in Switzerland have to pay contributions to mandatory private pension funds and the contribution rates increase with the workers' age (see Dorn and Sousa-Poza 2003). 
'involuntary' early retirement in a cross-national setting. This setting is essential when trying to assess the impact of national regulations (e.g. in the field of social security or employment protection legislation) on early retirement behavior. The main contribution of this paper is to provide international evidence on the extent to which early retirement is 'involuntary' and on the factors that influence the share of 'involuntary' early retirements. This is done by analyzing a unique international microdata set covering 19 countries. Given that 'voluntary' and 'involuntary' are intrinsically subjective concepts, we classify retirements as 'voluntary' or 'involuntary' according to workers' self-assessment. Our results show that the extent to which early retirement is involuntary varies greatly among countries. While rising unemployment rates and strict employment protection legislations increase the share of 'involuntary' retirements among the early retirees, more generous social security systems do not significantly affect the ratio of 'involuntary' to 'voluntary' early retirements.

The paper is structured as follows: Section 2 summarizes related theoretical and empirical literature, with a focus on Hutchens' (1999) model of retirement. This model is particularly illustrative for explaining reasons for 'involuntary' early retirement. Section 3 describes the data and variable definitions. Section 4 documents the prevalence of 'involuntary' early retirement in international comparison. Section 5 conducts an exploratory analysis of the determinants of 'voluntary' and 'involuntary' retirement and section 6 concludes.

\section{Related Literature}

Classical life-cycle models of retirement have focused on a worker's assessment of expected future streams of wage and pension payments as important determinants of the retirement date. Examples for this stream of literature are the contributions by Burkhauser 
(1979), Gordon and Blinder (1980), Mitchell and Fields (1982), Burtless (1986), and Gustman and Steinmeier (1986).

An important prediction from this literature is that earlier and more generous availability of public or private old-age benefits will increase the incidence of early exits from the labor force because early retirement becomes a more attractive choice for individuals. In particular, an exogenous and uniform increase of public or private pensions lowers the optimal retirement age due to equally directed substitution and wealth effects. Moreover, an additional incentive to choose an earlier retirement arises from pension systems where the present value of lifetime pension benefits falls when retirement is delayed.

International empirical studies such as those by Blöndal and Scarpetta (1998) or Duval (2003) confirm that early retirement is more prevalent in countries with more generous early retirement regulations. The two indicators used for the generosity of early retirement provisions are the old-age pension replacement rate which measures the expected pension income as a fraction of the earnings just prior to retirement, and the decrease in accumulated pension wealth accrual when postponing retirement, a measure for the actuarial (un-)fairness of a pension system. The importance of public pension schemes for retirement behavior is also highlighted by Gruber and Wise (1999) who show for various countries that retirement tends to take place around the age when early retirement benefits can be claimed.

While it is typically assumed that generous public early retirement provisions increase the incidence of early retirement because more workers choose to retire early ('voluntary' early retirement), Hutchens (1999) offers a competing explanation: Generous social security benefits can act as a form of unemployment insurance, effectively subsidizing workforce reductions by lowering the cost to the firm of shedding older workers. Public policy hence influences firms' willingness to encourage early retirement, and generous social security provisions for early retirement have the undesirable effect of reducing employment and creating 'involuntary' early retirement instead. 
Hutchens (1999) illustrates this idea with an implicit contract model of early retirement where a risk-neutral firm contracts with a risk-averse worker. The worker's risk aversion and the desire for consumption smoothing assure that the firm will enter into a three-period contract with the worker and thereby raising its profits. ${ }^{2}$ Under the contract, the worker is employed in the first period, either employed or early retired in the second period, and nonemployed in the third period. Employment status is hence only uncertain in the second period where an early retirement can take place.

Worker and firm negotiate a three-period contract over wages, private pensions, and the employment probability in period two. Public social security benefits in case of early retirement (second period) or in case of retirement at the standard retirement age (third period) as well as the degree of actuarial adjustment of these early retirement benefits are given exogenously. The contract between the firm and the worker defines the employment probability in period two as a function of the worker's productivity and of the marginal value of his consumption value of home production in that period. At the beginning of the first period - when the parties sign the contract - the realization of these two latter variables is yet unknown. In particular, there can be a shock to the demand for the firm's products in period two. Such a demand shock would imply that a second-period technology had to be used which did not match well with the worker's skills and hence lowers his productivity.

The firm chooses wages, private pensions, and the employment probability function for period two in order to maximizes its expected profit subject to the constraint that the worker's total expected utility must not be smaller than the (exogenous) utility that he could obtain from a job elsewhere in the labor market. The result of the firm's profit maximization is that

2 A related model is Lazear's (1979) model of mandatory retirement age. As a reaction to moral hazard, firms and workers agree on a contract that pays younger workers below and older workers above their marginal product. Such contracts make it less attractive for firms to employ older workers, and firms hence set a mandatory retirement age. 
the worker's employment status in the second period is determined by the following decision rule

If $\theta_{2} \geq \mathrm{z}_{2}+g_{2}-\Delta s$, the worker is employed

If $\theta_{2}<\mathrm{z}_{2}+g_{2}-\Delta s$, the worker is not employed (early retirement)

where $\theta_{2}$ and $z_{2}$ are productivity and consumption value of home production in period two, $\mathrm{g}_{2}$ are early retirement benefits available in period two, $\Delta$ is the degree of actuarial adjustment of these benefits, and s is the probability that the worker survives from the second to the third period. Neither wages, private pensions, nor third-period social security benefits enter the early retirement decision. In absence of social security, there would be an efficient solution where early retirement takes place whenever the productivity of the worker falls below his consumption value of home production, for instance as a consequence of a demand shock for the firm's products. However, generous social security benefits subsidize workforce reductions and lead to an inefficiently high level of early retirement: In accordance with the empirical evidence, the model predicts that higher early retirement benefits and a less-thanfull actuarial adjustment of such benefits (i.e., $\Delta<\mathrm{g}_{2} / \mathrm{s}$ ) will increase the incidence of early retirement.

The theoretical model by Hutchens (1999) highlights the possibility that generous social security benefits can incentivize firms to reduce their workforce, leading to 'involuntary' early retirement due to employment constraints. Using a pension reform in Finland as a natural experiment, Hakola and Uusitalo (2005) confirmed that firms react to public early retirement provisions by encouraging retirement. After the pension reform introduced an experiencerating of early retirement benefits which eliminated the subsidization of workforce reduction, early exits of older workers significantly decreased. This finding raises the question whether the positive effect of generous early retirement benefits on the incidence of early retirement is mostly due to a larger number of 'involuntary' and potentially inefficient firm-driven 
retirements rather than due to more workers who freely choose to retire early. The empirical section of this paper addresses this question.

An additional institutional factor that might contribute to such 'involuntary' early retirement is strict employment protection legislation. First of all, such legislation makes firms less likely to hire which is particularly detrimental for older workers who often find it more difficult to find a new job than younger workers. An older worker who can no longer work for his present employer will hence have few other choices than early retirement. Moreover, Schmähl (2003) reports for the case of Germany that since rigid employment protection legislation impedes firms from lying off workers, firms often pressurize older workers to retire early once they reach the age at which early retirement benefits become available.

Research on the motives for early retirement suggests that apart from the desire to leave work and apart from company restructurings, poor health is the third important cause for early retirement (see, e.g., Burtless and Quinn (2000) for the United States and Dorn and SousaPoza (2004) for Switzerland). At least part of the retirements due to poor health are 'involuntary'. While our data does not allow us to control for individual health, however, it does not seem plausible that major differences in health levels among the countries in our sample should exist which could explain the inter-country variance in the proportion of 'involuntary' early retirements. In the empirical section of the paper, we will, as a robustness test, control for life expectancy as a crude measure for a country's health level.

\section{Data and Definitions}

According to OECD (1995), three broad definitions of retirement can be distinguished: (i) being a recipient of a public or private old-age pension, regardless of the current employment 
status; (ii) being out of the labor force, regardless of the reason for ceasing work and no matter whether an old-age pension is being drawn; or (iii) having a self-described status of retired, regardless of employment status and receipt of a pension. These definitions of retirement can easily be transformed into definitions of early retirement if the retirement takes place prior to the individual reaching the legally defined standard retirement age.

In this paper, early retirement is defined based on a combination of the second and third concept. A person is hence considered as a retiree if he is not working and reports his employment status as 'early retired' (the same definition is used, e.g., by Smith 2006).

The international analysis of 'voluntary' and 'involuntary' early retirement is conducted using data from the 1997 International Social Survey Program (ISSP). The ISSP is a continuing annual program of cross-national collaboration which started in 1985. The data are collected by independent institutions in the participating countries using the same questionnaire. The topics of the annual surveys change from year to year. In 1997, 34,835 individuals were interviewed on "Work Orientations", covering issues on work content and organization as well as general attitudes towards work and leisure. Our analysis includes the following 19 countries: Canada, Cyprus, Denmark, France, Germany, Great Britain, Hungary, Italy, Japan, the Netherlands, New Zealand, Norway, Poland, Portugal, Slovenia, Spain, Sweden, Switzerland, and the USA. ${ }^{3}$

As laid out above, the ISSP data allows us to identify individuals who (i) were no longer working and who (ii) assessed their own status as being early retired. All early retired persons had to state either "I retired early - by choice" or "I retired early - not by choice". We use this to define a dichotomous dependent variable having a value equal to one if the respondent retired early in an involuntary manner ("not by choice"), and equal to zero if early retirement was voluntary ("by choice"). Using a self-assessed measure is appropriate given that

3 Six developing countries from Asia and Eastern Europe were excluded from the analysis because the data set contained very few early retirement observations for these countries. 
'voluntary' and 'involuntary' are intrinsically subjective concepts. The potential measurement error introduced by the subjective variable trades off against a degree of arbitrariness that inevitably arises from classifying retirements as 'voluntary' and 'involuntary' using some combination of objective criteria. Empirically, subjective and objective definitions of 'involuntary' early retirements yield similar results. Desmet et al. (2005) find for the case of Belgium that subjective and objective classifications of retirements as 'voluntary' and 'involuntary' yield almost exactly the same share of 'involuntary' retirements. Moreover, Tanner (1998) and Smith (2006) observe strong links between self-assessed involuntary reasons for early retirement and an 'objective' measure of involuntary retirement such as moving into retirement from a non-working status.

The dichotomous variable for 'involuntary' early retirement is analyzed with a series of probit models. The analysis covers the early retirement of individuals aged 45 to 64 who retired between 1983 and 1997. This broad definition allows for a reasonable sample size of 651 early retirees in the multivariate analysis. Table A1 in the appendix summarizes the corresponding explanatory variables. ${ }^{4}$

In addition to the ISSP variables, our analysis includes variables referring to general economic and social security characteristics of the different countries. These macro-level variables are included to test the theoretical predictions that were discussed in section 2 of this paper. Product demand shocks, which can trigger early retirement in the framework of Hutchens (1999), are characterized by the increase of the unemployment rate between the year before the retirement and the year of retirement. The data sources for this variable and

4 The main advantage of the ISSP data is that it allows us to identify voluntary and involuntary early retirement in an international setting and on a micro-data level. The limitation of the data is that it is only cross-sectional. We can therefore not identify specific characteristics of individuals' pre-retirement jobs such as occupation. Moreover, it is not possible to readily compare early retired individuals to people who did not retire early since the identification of persons belonging to the latter group is difficult given the lack of information on previous working status (see also Dorn and Sousa-Poza 2005 for a further discussion of this issue). 
for the OECD Employment Protection Legislation Index ${ }^{5}$ for the year 1990 are OECD (1999) and (2004b), respectively.

There are two main characteristics of old-age pensions systems that supposedly affect early retirement. First, the expected old-age pension replacement rate at a given age measures the expected pension income as a fraction of the earnings just prior to retirement. The replacement rate can thus be interpreted as an indicator for the generosity of an old-age pension system. ${ }^{6}$ Second, the decrease in accumulated pension wealth accrual measures the reduction in expected lifetime pension income that results from postponing retirement. Such a decline in pension wealth accrual is equivalent to an implicit tax on continued work and is characteristic for a pension system that is actuarially unfair. In an actuarially neutral pension system, pension wealth accrual is invariant to the retirement age. Our models include variables for the average old-age pension gross replacement rate between age 60 and for the decrease in accumulated pension wealth accrual when postponing retirement from age 55 to 64. These variables take into account both public social security pensions and mandatory private pensions. The pension replacement rate data has been provided by Romain Duval (part of this data is published in Duval, 2003, p. 39), while the pension wealth accrual data is taken from Blöndal and Scarpetta (1998, p. 65). ${ }^{7}$ As a measure of a country's income level, the models also include GDP per capita in the year of an individual's early retirement. The data is taken from Penn World Tables (Heston et al. 2002). It would of course be desirable to include

5 The index refers to the strictness of employment protection for regular employment and is based on a variety of criteria including notice period, amount of severance pay, and definition of unfair dismissal.

6 In a life-cycle framework with certain restrictive conditions, the level of public pensions should have no effect on the choice of a retirement date. This is the case if contributions to the pension system are perceived as savings, if pension benefits paid equal the amount of contributions paid, and if the interest rate equals the rate of growth of total wages.

7 Duval (2003) computed the pension replacement rates are a synthetic indicator based on six individual cases with different wage levels and different marital status. Pension wealth accruals reported by Blöndal and Scarpetta (1998) are computed based on singles with average wages. The macro-level variables are summarized in table A1 in the appendix. Note that some of the OECD variables are not available for four countries in our sample (Cyprus, Hungary, Poland, and Slovenia). The multivariate analysis will hence be restricted to the remaining 15 countries. 
individual-level financial data, particularly individual pension wealth. However, the ISSP does not contain such information.

A concern that regularly arises in international surveys is that respondents' answers might be affected by the fact that questions asked in different languages can have slightly different meanings. Furthermore, answers may be influence by different cultural attitudes. Dorn et al. (2007) have shown that levels of self-reported happiness indeed vary significantly across language regions, with the a borderline being between the Germanic languages (including English) on the one hand, and Romance and Slavic languages on the other hand. While it seems unlikely that an assessment whether a retirement has been by choice or not is subject to strong language or cultural effects, we control for language groups as a robustness test in the empirical section of the paper.

\section{Incidence of Involuntary Early Retirement}

The incidence of involuntary early retirement varies considerably among countries, as shown in table 1. In the USA and in Denmark, only one out of ten early retirees has involuntarily moved into retirement. Other countries with very low rates of forced early retirement are Canada, Japan, and Norway. Conversely, involuntary early retirement seems to be the rule rather than the exception in some continental European countries. In Germany, Portugal, and Hungary, more than half of all early retirements are 'not by choice'.

Clearly, these large international differences in the incidence of 'involuntary' early retirement call for an explanation. In section 5, we test whether labor market and pension system characteristics contribute to these differences. 
Table 1: 'Involuntary' Early Retirements as a Percentage of all Early Retirements, Early Retirees per Worker

\begin{tabular}{lcc}
\hline Country & $\begin{array}{c}\text { Percentage of 'Involuntary' Early } \\
\text { Retirement }\end{array}$ & $\begin{array}{c}\text { Early Retirees per Worker, age } \\
\text { group 45-69 }\end{array}$ \\
\hline Hungary & $62.1 \%$ & 0.342 \\
Portugal & $54.2 \%$ & 0.165 \\
Germany & $50.0 \%$ & 0.183 \\
Slovenia & $46.3 \%$ & 0.344 \\
France & $41.0 \%$ & 0.081 \\
Poland & $40.4 \%$ & 0.269 \\
Sweden & $37.5 \%$ & 0.093 \\
Spain & $32.5 \%$ & 0.328 \\
Great Britain & $28.9 \%$ & 0.247 \\
Italy & $28.6 \%$ & 0.174 \\
New Zealand & $26.2 \%$ & 0.109 \\
Switzerland & $20.5 \%$ & 0.118 \\
Cyprus & $17.1 \%$ & 0.175 \\
Netherlands & $16.7 \%$ & 0.300 \\
Japan & $15.9 \%$ & 0.033 \\
Norway & $13.0 \%$ & 0.062 \\
Canada & $12.2 \%$ & 0.196 \\
United States & $9.4 \%$ & 0.080 \\
Denmark & $8.8 \%$ & 0.132 \\
\hline
\end{tabular}

Source: Based on ISSP 1997 data. Countries are sorted by the first data column.

A notable observation is that all three Eastern European countries in the sample, Hungary, Slovenia, and Poland, have large shares of 'involuntary' retirement. These countries have been affected large industrial restructurings when moving from a state economy to a market economy (see Stanojevi (2003) for Slovenia). Moreover, they differ from the rest of the sample by having lower health levels and supposedly more retirements due to poor health (see Szalai (1991) for the case of Hungary).

Since some of the OECD macro-level data is not available for the Eastern European countries, they are not included in the multivariate analysis in section 5 of the paper which focuses on a more homogeneous sample of OECD countries with well-established industrialized market economies. Even among these countries, striking differences in the share of involuntary early retirements remain, even among neighboring countries such as Norway and Sweden. 
In addition to the incidence of involuntary early retirement, table 1 also contains a measure for the general prevalence of early retirement (both 'voluntary' and 'involuntary') in the respective countries. This measure is the ratio of early retirees per active worker in the age group 45 to 69. Again, large international differences can be observed. In Hungary, Slovenia, and Spain, this early retirement ratio exceeds 0.3 , while there are less than 0.1 early retired persons per active worker in the United States, Japan, or Norway.

Table 2: Correlations between Share of 'Involuntary' Early Retirement, Early Retirees per Worker, and Labor Force Participation Rate

\begin{tabular}{lccc}
\hline & $\begin{array}{c}\text { Share of 'Involuntary' } \\
\text { Early Retirement }\end{array}$ & $\begin{array}{c}\text { Early Retirees per } \\
\text { Worker }\end{array}$ & $\begin{array}{c}\text { Labor Force } \\
\text { Participation Rate } \\
\text { (age 55-64) }\end{array}$ \\
\hline Pearson Correlation & & & \\
\hline $\begin{array}{l}\text { Share of 'Involuntary' } \\
\text { Early Retirement }\end{array}$ & 1.000 & $0.461^{* *}$ & $-0.518^{* *}$ \\
$\begin{array}{l}\text { Early Retirees per } \\
\text { Worker }\end{array}$ & $(\mathrm{n}=19)$ & 1.000 & $(\mathrm{p}=0.033, \mathrm{n}=17)$ \\
Labor Force & $(\mathrm{n}=19)$ & $-0.728^{* * *}$ \\
$\begin{array}{l}\text { Participation Rate } \\
\text { (age 55-64) }\end{array}$ & & $(\mathrm{p}=0.001, \mathrm{n}=17)$ \\
\hline Kendall's Tau-b Correlation & & & 1.000 \\
\hline $\begin{array}{l}\text { Ratio of 'Involuntary' } \\
\text { Early Retirement }\end{array}$ & 1.000 & $0.287^{*}$ & $(\mathrm{n}=17)$ \\
$\begin{array}{l}\text { Early Retirees per } \\
\text { Worker }\end{array}$ & $(\mathrm{n}=19)$ & 1.000 & $-0.529^{* * *}$ \\
$\begin{array}{l}\text { Labor Force } \\
\text { Participation Rate } \\
\text { (age 55-64) }\end{array}$ & $(\mathrm{n}=19)$ & $(\mathrm{p}=0.003, \mathrm{n}=17)$ \\
\hline
\end{tabular}

Sources: Share of 'involuntary' early retirement and early retirees per worker based on ISSP 1997 data, labor force participation rate 1997 based on OECD (2004a). */**/*** denote significance at the 10\%/5\%/1\%-level. Note that the OECD data does not contain participation rates for Cyprus and Slovenia.

Table 2 reports the correlations between the share of 'involuntary' early retirements as a percentage of all retirements, early retirements per worker, and labor force participation rates. It is not surprising that there is a highly significant negative correlation between the early retirement ratio and the labor force participation rate of older persons (age 55 to 64), because a high incidence of early retirement is a main reason for low participation rates. A striking result, however, is the significant and relatively sizable positive correlation between the 
percentage of 'involuntary' early retirement among early retirees and the number of early retirees per worker. Countries with a large proportion of involuntary early retirement tend to have lower participation rates. These results accentuate the empirical importance of involuntary early retirement, and they establish a link between the relative proportion of involuntary early retirement among early retirees, which will be analyzed in section 5 , and the overall incidence of early retirement and labor force participation.

\section{Determinants of Involuntary Early Retirement}

We estimate a series of probit models that analyze the determinants of the probability that an early retirement has been 'involuntary'. The sample contains observations of early retired persons from 15 OECD member countries. ${ }^{8}$ It includes individuals who went into early retirement between 1983 and 1997 and at ages between 45 and 64. Weights are adjusted to give every country the same weight in the total sample. Furthermore, the Moulton (1990) problem that is associated with estimating the effects of macro-level variables on micro units is taken into account by clustering standard errors by countries using the standard technique described by Froot (1989).

The main focus of the analysis is on the impact of various social security and labor market variables on 'involuntary' early retirement. For the generosity of social security early retirement provisions, there are two competing hypotheses. If generous benefits (represented by high pension replacement rates and decreasing pension wealth accruals) increase the number of early retirements mainly because more workers choose to retire under more attractive financial terms, then favorable early retirement provisions should have a negative

8 Canada, Denmark, France, Germany, Great Britain, Italy, Japan, Netherlands, New Zealand, Norway, Portugal, Spain, Sweden, Switzerland, and the USA. 
impact on the share of 'involuntary' retirements. Conversely, in the framework of the theory by Hutchens (1999), we would expect that favorable early retirement provisions of social security systems and adverse economic conditions (represented by increasing unemployment rates) lead to company-driven early retirements, which tend to be 'involuntary' from a worker's perspective. Furthermore, we hypothesize that stricter employment protection will increase the incidence of 'involuntary' early retirements.

Table 3 shows probit estimations of the determinants of involuntary early retirement. Apart from social security and labor market characteristics, the estimated models also control for the socio-demographic factors gender, marital status, and age at retirement, as well as for the year of retirement.

Model (I) in table 3 considers the impact of the socio-demographic variables and national income on the probability that an early retirement was 'involuntary'. Gender and marital status do not have significant effects when we allow for a gender-specific impact of marriage by including an interaction term between gender and marriage. ${ }^{9}$ We also estimated the models (II) for both genders separately, but found no gender-specific impact of the institutional variables. ${ }^{10}$

It is not surprising that early retirements at age 45 to 59 are more often 'involuntary' than retirements at age 60 to 64 . A 'voluntary' early retirement only becomes an attractive option once an individual has had enough time to accumulate a sufficient level of private and public pension wealth to fund consumption in old age. The variables for retirement years do not show a clear trend in the proportion of 'involuntary' early retirement, although from 1995 to 1997, this proportion has been significantly larger than in the reference period 1983 to 1985.

$9 \quad$ Several empirical studies such as Pozzenbon and Mitchell (1989), Peracchi and Welch (1994), and Bütler et al. (2004) have found that married women tend to retire earlier than married men, possibly because "married women appear to value nonwork years highly" (Pozzenbon and Mitchell 1989, p. 20).

10 The gender-specific results are not shown here because they yield little additional insights. These results are available from the authors upon request. 
Higher national GDP per capita is associated with a larger share of 'voluntary' early retirement. The higher income level, which is typically correlated with higher wealth, makes 'voluntary' early retirement better affordable for workers. According to Burtless and Quinn (2000), an increasing level of wealth is even the most powerful explanation for the trend to earlier retirement that most industrialized countries experienced during the past 50 years. 


\section{Table 3: Probit estimations of the determinants of 'involuntary' early retirement in} 15 countries

Dependent Variable: Involuntary Early Retirement (=1 if early retirement was involuntary, $=0$ if early retirement was by choice)

Model (I) Model (II)

\begin{tabular}{|c|c|c|c|c|}
\hline Intercept & 0.716 & $(0.501)$ & 0.211 & $(0.695)$ \\
\hline Female & -0.171 & $(0.305)$ & -0.164 & $(0.305)$ \\
\hline Married & -0.130 & $(0.190)$ & -0.162 & $(0.189)$ \\
\hline Female x Married & -0.183 & $(0.340)$ & -0.186 & $(0.339)$ \\
\hline Retirement age 55-59 & $0.475 * * *$ & $(0.124)$ & $0.488 * * *$ & $(0.129)$ \\
\hline Retirement age 50-54 & $0.613^{* * *}$ & $(0.183)$ & $0.675^{* * *}$ & $(0.206)$ \\
\hline Retirement age 45-49 & $0.612^{* *}$ & $(0.267)$ & $0.688 * *$ & $(0.287)$ \\
\hline Early retired in 1995-1997 & $0.527 *$ & $(0.280)$ & $0.551 *$ & $(0.321)$ \\
\hline Early retired in 1992-1994 & 0.145 & $(0.256)$ & 0.032 & $(0.256)$ \\
\hline Early retired in 1989-1991 & 0.280 & $(0.268)$ & 0.285 & $(0.275)$ \\
\hline Early retired in 1986-1988 & -0.051 & $(0.339)$ & -0.003 & $(0.361)$ \\
\hline $\begin{array}{l}\text { Real GDP p.c. (year of } \\
\text { retirement) }\end{array}$ & $-0.090 * * *$ & $(0.015)$ & $-0.074 * * *$ & $(0.022)$ \\
\hline $\begin{array}{l}\text { Average pension gross } \\
\text { replacement rate (age 60-64) }\end{array}$ & & & -0.251 & $(0.197)$ \\
\hline $\begin{array}{l}\text { Decrease of pension wealth } \\
\text { accrual (age } 55 \text { to age 64) }\end{array}$ & & & 0.024 & $(0.025)$ \\
\hline $\begin{array}{l}\text { Change of unemployment rate } \\
\text { (year of retirement) }\end{array}$ & & & $0.121^{* * *}$ & $(0.046)$ \\
\hline $\begin{array}{c}\text { OECD employment protection } \\
\text { legislation index }\end{array}$ & & & $0.102 *$ & $(0.059)$ \\
\hline Number of observations & \multicolumn{2}{|c|}{651} & \multicolumn{2}{|c|}{651} \\
\hline Log pseudo-likelihood & \multicolumn{2}{|c|}{-331.208} & \multicolumn{2}{|c|}{-326.986} \\
\hline \multicolumn{5}{|c|}{ Wald tests for joint insignificance } \\
\hline \multicolumn{3}{|c|}{ Pension gross replacement rate $=$ pension wealth accrual $=0$} & \multicolumn{2}{|c|}{2.04} \\
\hline \multicolumn{3}{|c|}{ Average unemployment rate $=$ employment protection legislation $=0$} & \multicolumn{2}{|c|}{$10.14 * * *$} \\
\hline
\end{tabular}

Notes: The reference person is male, unmarried, and has retired between age 60 and 64 and between the years 1983 to 1985. Standard errors are clustered by country and shown in parenthesis. Observations are weighted with "federal" weights that give each country the same weight in the total sample. The Wald statistics have Chi-square distributions with 2 degrees of freedom. $* / * * / * * *$ denotes significance at the 10/5/1-percent level. 
Model (II) adds the macro-level variables that characterize labor market conditions and pension system characteristics. The proportion of involuntary retirement is significantly higher in years with increasing unemployment rates. One explanation for this finding is Hutchens' (1999) theory that firms promote early retirement when they are confronted with adverse demand shocks in an economic recession. For the case of Switzerland, Dorn and Sousa-Poza (2004) have shown that there is indeed a parallel movement of the unemployment rate and the portion of early retirement that is due to company reorganizations.

Employment protection legislation is, in accordance with our hypothesis, another factor that can create employment restrictions which lead to 'involuntary' early retirement. Indeed, countries with more rigid employment protection as measured by the OECD index have significantly higher shares of 'involuntary' retirement. The effect is sizable: one additional index point raises the share of 'involuntary’ early retirements by 3\%, all else hold equal.

The social security variables yield a differentiated picture. A high decrease in pension wealth accrual between age 55 and age 64, which indicates an actuarially unfair pension system, is associated with a somewhat larger share of 'involuntary' retirements. In contrast, a higher pension gross replacement rate rather tends to increase the share of 'voluntary' early retirements. The null hypotheses that the coefficients of these variables are separately or jointly equal to zero can, however, not be rejected at conventional significance levels. The generosity indicators for the social security systems' early retirement provisions, which Blöndal and Scarpetta (1998) and Duval (2003) identified as main determinants for the differences in the incidence of early retirement across a similar sample of OECD countries, do not significantly affect the shares of 'voluntary' and 'involuntary' early retirements. This suggests that more generous early retirement provisions of the social security system create both more 'voluntary' and more 'involuntary' early retirement. The incidence of early retirement hence not only increases because more workers freely choose to retire, but likely 
also because the social security system creates incentives for firms to shed older workers for whom the social security system will pay thereafter.

As a robustness test for these results, table 4 shows two extensions of model (II) which contain additional macro-level variables. Model (III) incorporates life expectancy at birth as a rough indicator for the national health level. A better health level (higher life expectancy) slightly decreases the share of 'involuntary' early retirements. However, the effect is statistically insignificant. Coefficients and significance levels of the labor market and social security variables remain unaffected. Since there is little variation in health levels between the countries in the sample, it is not surprising that health contributes little to the explanation of the large differences in the share of 'involuntary' early retirements across countries.

Table 4: Robustness Tests

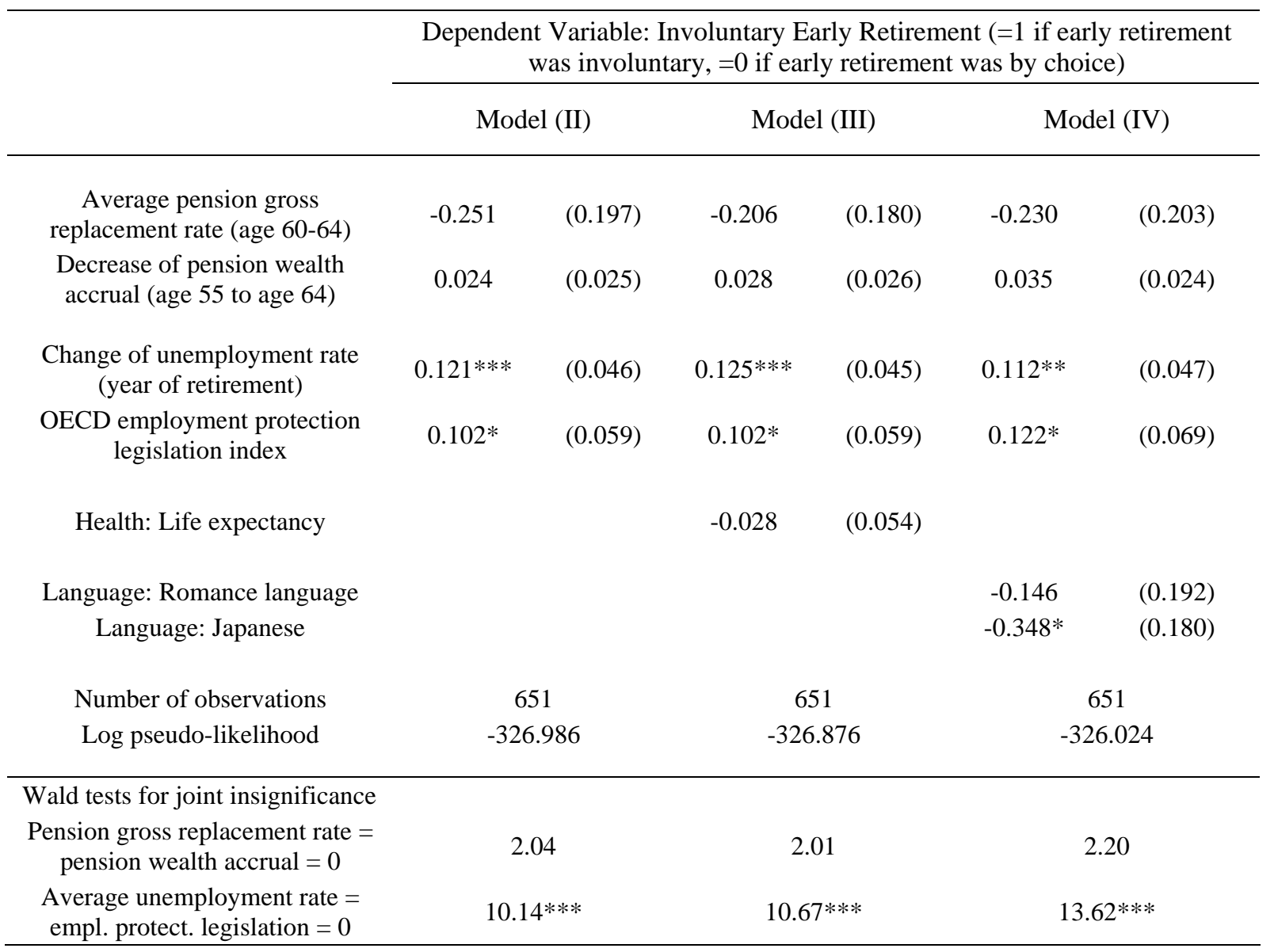

Notes: The reference person is male, unmarried, and has retired between age 60 and 64 and between the years 1983 to 1985. The reference category for the language families is 'Germanic languages'. Standard errors are clustered by country and shown in parenthesis. Observations are weighted with "federal" weights that give each country the same weight in the total sample. The Wald statistics have Chi-square distributions with 2 degrees of freedom. */**/*** denotes significance at the 10/5/1percent level. 
Given that the international data comes from a survey that used different languages, we also test whether answers of the survey respondents depend on language. The national languages of the countries in the sample can be classified into three language families: Germanic languages (including English), Romance languages, and Japanese. Model (IV) includes dummy variables for Romance language and Japanese, the countries with Germanic languages being the reference group. The results in table 4 show that only the variable for Japanese, which is a dummy variable for a single country, is significant. The two large language blocks in the sample, countries with Germanic languages and countries with Romance languages, do not differ significantly with regard to the share of 'involuntary' retirements, once individual variables and characteristics of labor markets and social security systems are controlled for. When interpreting language as a measure of culture (see Lazear 1999), this result implies that the international differences in the share of self-reported 'involuntary' early retirements are not due to differences in cultural attitudes across (groups of) countries. The coefficients of the other macro-level variables are unaffected by the inclusion of the language variables.

\section{Summary and Conclusions}

Microeconomic theory has mostly analyzed retirement as an active and well-planned choice of the worker. However, recent literature such as Desmet et al. (2005) and Smith (2006) points out the importance of distinguishing between 'voluntary' and 'involuntary' early retirement. 'Involuntary' early retirement is still a rational choice of the worker, but one that is typically driven by employment constraints. Hutchens (1999) developed a model of a firm that uses social security early retirement benefits as a form of unemployment insurance. The 
model predicts that, in order to reduce staff during economic recessions, companies force individuals into early retirement. Particularly in Europe, there is extensive anecdotal evidence suggesting that many workers only retire early because of employment constraints. Given that older workers face difficulties in finding a new job, workers who lose their present employment often see no other choice than moving into an 'involuntary' early retirement.

This paper provides an international empirical analysis of 'voluntary' and 'involuntary' early retirement based on a self-assessed measure taken from the International Social Survey Programme (ISSP) data. A particular focus is on the impact of social security and labor market characteristics on 'involuntary' early retirement. The results support the notion that 'involuntary' early retirement is an empirically important phenomenon in Europe. A striking fact is that in some countries, including Germany and Portugal, more than half of the early retirees state that their retirement was 'not by choice'. This contrasts with other countries such as the USA, where only few early retirements are 'not by choice'. The share of 'involuntary' early retirements is particularly high in countries with low labor market participation rates of older persons.

The empirical analysis shows that an increasing unemployment rate yields a larger share of involuntary early retirement. This result suggests that companies encourage early retirements to reduce staff during economic slowdowns. More rigid employment protection legislation does also increase the share of involuntary early retirements. Such legislation creates employment constraints by making firms less likely to hire, and the result is also consistent with Schmähl's (2003) observation that some companies in Germany push older workers into early retirement as a means to circumvent strict employment protection legislation.

Previous empirical studies report that generous early retirement provisions of social security systems lead to more early retirement. However, this study finds that favorable early retirement provisions such as a high replacement rate and little actuarial adjustment of early 
retirement benefits do not increase the share of 'voluntary' early retirements. Attractive early retirement conditions of the social security system do hence not only trigger more 'voluntary' early retirements, but also more 'involuntary' early retirements. A likely explanation for this finding is that generous social security benefits make it more attractive for firms to reduce their workforce using early retirement programs, as Hakola and Uusitalo (2005) have confirmed for the case of Finland.

This paper shows that in many European countries, an astonishing share of early retirees reports to have retired 'not by choice'. It provides some first explanations for the international differences in the prevalence of 'involuntary' early retirement. Further research may analyze how institutions and company policies within a country affect 'involuntary' early retirements. Moreover, post-retirement behavior of the 'involuntary' retired may likely differ from that of 'voluntary' retirees.

\section{References}

Blöndal, S., S. Scarpetta (1998): "The Retirement Decision in OECD Countries", OECD Economics Department Working Papers No.(98)15.

Burkhauser, R.V. (1979): "The Pension Acceptance Decision of Older Workers", Journal of Human Resources 14(1): 63-75.

Burtless, G. (1986): "Social Security, Unanticipated Benefit Increases, and the Timing of Retirement", Review of Economic Studies 53: 781-805.

Burtless, G. and J.F. Quinn (2000): "Retirement Trends and Policies to Encourage Work Among Older Americans", Boston College Working Papers in Economics No.436. 
Bütler, M., O. Huguenin and F. Teppa (2005): "What Triggers Early Retirement? Results from Swiss Pension Funds", C.E.P.R. Discussion Paper No.4394.

Desmet, R., A. Jousten and S. Perelman (2005): "The Benefits of Separating Early Retirees from the Unemployed: Simulation Results for Belgian Wage Earners", C.E.P.R. Discussion Paper No.5077.

Dorn, D. and A. Sousa-Poza (2005): "The Determinants of Early Retirement in Switzerland", Swiss Journal of Economics and Statistics 141(2): 247-283.

Dorn, D., J.A.V. Fischer, G. Kirchgässner and A. Sousa-Poza (2007): "Is it Culture or Democracy? The Impact of Democracy, Income and Culture on Happiness", Social Indicators Research (forthcoming).

Dorn, D. and A. Sousa-Poza (2004): "Motives for Early Retirement: Switzerland in an International Comparison", Discussion Paper of the Research Institute for Labor Economics and Labor Law at the University of St Gallen No.99.

Dorn, D. and A. Sousa-Poza (2003): "Why is the employment rate of older Swiss so high? ", Geneva Papers on Risk and Insurance 28: 652-674.

Duval, R. (2003): "The Retirement Effects of Old-Age Pension and Early Retirement Schemes in OECD Countries", OECD Economics Department Working Papers No. (2003) 24.

Froot, K.A. (1989): "Consistent Covariance Matrix Estimation with Cross-Sectional Dependence and Heteroskedasticity in Financial Data", Journal of Financial and Quantitative Analysis 24(3): 333-355.

Gordon, R.H. and A.S. Blinder (1980): "Market Wages, Reservation Wages, and Retirement Decisions", Journal of Public Economics 14: 277-308.

Gruber, J. and D.A. Wise (1999): Social Security and Retirement around the World. Chicago: University of Chicago Press. 
Gustman, A.L. and T.L. Steinmeier (2000): "Retirement in Dual-Career Families: A Structural Model", Journal of Labor Economics 18: 503-545.

Gustman, A.L. and T.L. Steinmeier (1986): "A Structural Retirement Model", Econometrica 54: pp. 555-584.

Hakola, T. and R. Uusitalo (2005): "Not so voluntary retirement decisions? Evidence from a pension reform", Journal of Public Economics 89: 2121-2136.

Henkens, K. and H.P. van Dalen (2003): "Early retirement systems and behavior in an international perspective", in G. Adams and T.H. Beehr (eds.): Retirement: Reasons, Processes and Results, New York: Springer, 242-263.

Herz, D.E. (1995): "Work after early retirement: an increasing trend among men", Monthly Labor Review 118(4): 13-20.

Heston, A., R. Summers and B. Aten (2002): Penn World Table Version 6.1, Center for International Comparisons at the University of Pennsylvania (CICUP), October 2002.

Hurd, M.D. (1990): "Research on the Elderly: Economic Status, Retirement, and Consumption and Saving", Journal of Economic Literature 28(2): 565-637.

Hutchens, R. (1999): "Social Security Benefits and Employer Behavior: Evaluating Social Security Early Retirement Benefits as a Form of Unemployment Insurance", International Economic Review 40(3): 659-678.

Lazear, E.P. (1979): "Why Is There Mandatory Retirement? ", Journal of Political Economy 87(6): 1261-1284.

Lazear, E.P. (1999): "Culture and Language", Journal of Political Economy, Vol. 107(6): 95126.

Mitchell, O.S. and G.S. Fields (1982): "The Effects of Pensions and Earnings on Retirement: A Review Essay", in Ehrenberg, R.G. (ed.), Research in Labor Economics, Vol. 5. London: JAI Press. 
Moulton, B.R. (1990): "An Illustration of a Pitfall in Estimating the Effects of Aggregate Variables on Micro Units", The Review of Economics and Statistics 77(2): 334-338.

OECD (2004a): OECD Employment Outlook. Paris: OECD.

OECD (2004b): OECD Labor Force Statistics - Indicators. Online database statistics, version December 15, 2004.

OECD (2002): Labour Force Statistics 1981-2001. Paris: OECD.

OECD (1995): The Transition from Work to Retirement. Social Policy Studies No. 16. Paris: OECD.

Peracchi, F. and F. Welch (1994): "Trends in Labor Force Transitions of Older Men and Women", Journal of Labor Economics, 12(2): 210-242.

Pozzenbon, S. and O.S. Mitchell (1989): "Married Women's Retirement Behavior", Journal of Population Economics, 2(1): 39-53.

Schmähl, W. (2003): "Ageing Workforce: Firm Strategies and Public Policy in Germany", Geneva Papers on Risk and Insurance, 28: 575-595.

Smith, S. (2006): "The Retirement-Consumption Puzzle and Involuntary Early Retirement: Evidence from the British Household Panel Survey", The Economic Journal, 116: C130-C148.

Stanojevi, M. (2003): "Workers' Power in Transition Economies: the Cases of Serbia and Slovenia", European Journal of Industrial Relations, 9: 283-301.

Szalai, J. (1991): "Hungary: Exit from the State Economy", in: Kohli, M., Rein, M., Guillemard, A.-M., and van Gunsteren, H. (eds.), Time for Retirement - Comparative Studies of Early Exit from the Labor Force. Cambridge: Cambridge University Press.

Tanner, S. (1998): "The Dynamics of Male Retirement Behaviour", Fiscal Studies 19(2): 175196.

Taylor, P. (2001): Analysis of Ways to Improve Employment Opportunities for Older Workers. Report to the European Commission, November 2001. 
United Nations (2005): World Population Prospects. The Revision 2004. New York: United Nations. 


\section{Appendix}

Table A1: Definitions and descriptive statistics of variables

\begin{tabular}{|c|c|c|c|c|c|}
\hline $\begin{array}{l}\text { Variable name or } \\
\text { variable group }\end{array}$ & $\begin{array}{l}\text { Definition and source (if other than ISSP } \\
\text { 1997) }\end{array}$ & Mean & S.D. & Min. & Max. \\
\hline $\begin{array}{l}\text { Involuntary early } \\
\text { retirement }\end{array}$ & $\begin{array}{l}1 \text { if early retirement was 'not by choice' / } 0 \\
\text { if early retirement was 'by choice' }\end{array}$ & 0.26 & 0.44 & 0 & 1 \\
\hline Female & 1 if female & 0.39 & 0.49 & 0 & 1 \\
\hline Married & 1 if married & 0.73 & 0.44 & 0 & 1 \\
\hline Female x Married & 1 if female and married & 0.22 & 0.42 & 0 & 1 \\
\hline Retirement age & $\begin{array}{l}1 \text { if retired at age } 60-64 \\
1 \text { if retired at age } 55-59 \\
1 \text { if retired at age } 50-54 \\
1 \text { if retired at age } 45-49\end{array}$ & $\begin{array}{l}0.46 \\
0.38 \\
0.12 \\
0.04\end{array}$ & $\begin{array}{l}0.50 \\
0.49 \\
0.33 \\
0.20\end{array}$ & 0 & 1 \\
\hline Retirement year & $\begin{array}{l}1 \text { if retired in 1995-1997 } \\
1 \text { if retired in 1992-1994 } \\
1 \text { if retired in 1989-1991 } \\
1 \text { if retired in 1986-1988 } \\
1 \text { if retired in 1983-1985 }\end{array}$ & $\begin{array}{l}0.30 \\
0.26 \\
0.20 \\
0.14 \\
0.11\end{array}$ & $\begin{array}{l}0.46 \\
0.44 \\
0.40 \\
0.35 \\
0.31\end{array}$ & 0 & 1 \\
\hline $\begin{array}{l}\text { Real GDP p.c. (year } \\
\text { of retirement) }\end{array}$ & $\begin{array}{l}\text { National real GDP per capita in K USD in } \\
\text { year of retirement. Source: Penn World } \\
\text { Tables (Heston et al. 2002). }\end{array}$ & 19.66 & 3.88 & 9.00 & 30.19 \\
\hline $\begin{array}{l}\text { Average pension } \\
\text { gross replacement } \\
\text { rate (age } 60 \text { to age } \\
64 \text { ) }\end{array}$ & $\begin{array}{l}\text { Average gross pension income from public } \\
\text { and mandatory private occupational } \\
\text { schemes between age } 60 \text { and age } 64 \text { for a } \\
\text { person who retired at age } 60 \text { measured for } \\
\text { the individual year of retirement, as a } \\
\text { multiple of pre-retirement annual income. } \\
\text { Computed as an average of six cases with } \\
\text { three different income levels and two } \\
\text { marital statuses. Source: OECD (data } \\
\text { summarized in Duval 2003, p. 39, } \\
\text { comprehensive data provided by Duval). }\end{array}$ & 0.32 & 0.31 & 0.00 & 0.80 \\
\hline $\begin{array}{l}\text { Decrease of pension } \\
\text { wealth accrual (age } \\
55 \text { to age } 64 \text { ) }\end{array}$ & $\begin{array}{l}\text { Decrease in total pension wealth by } \\
\text { continuing work from age } 55 \text { to age } 64 \text {, as a } \\
\text { multiple of the income at age } 55 \text {. Computed } \\
\text { based on singles with average wages. } \\
\text { Source: OECD (Blöndal and Scarpetta } \\
\text { 1999, p. 65). }\end{array}$ & 1.12 & 1.40 & -0.40 & 7.90 \\
\hline $\begin{array}{l}\text { Change of } \\
\text { unemployment rate } \\
\text { (year of retirement) }\end{array}$ & $\begin{array}{l}\text { Change of the national unemployment rate } \\
\text { between the year before retirement and the } \\
\text { year of retirement in percentage points. } \\
\text { Source: OECD (1999). }\end{array}$ & -0.00 & 1.00 & -2.70 & 4.30 \\
\hline $\begin{array}{l}\text { OECD employment } \\
\text { protection legislation } \\
\text { index }\end{array}$ & $\begin{array}{l}\text { OECD index for rigidity of employment } \\
\text { protection legislation in 1990. Higher } \\
\text { values represent a stricter legislation. } \\
\text { Source: OECD (2004b). }\end{array}$ & 2.40 & 1.23 & 0.20 & 4.10 \\
\hline Life expectancy & $\begin{array}{l}\text { Life expectancy at birth 1990. Source: } \\
\text { United Nations (2005). }\end{array}$ & 78.30 & 1.02 & 76.5 & 80.5 \\
\hline
\end{tabular}

